\title{
Coulisses
}

Revue de théâtre

15 | Hiver 1997

Varia

\section{Un accueil quasi religieux}

\section{Sandrine Mondy}

\section{(2) OpenEdition}

\section{Journals}

Édition électronique

URL : http://journals.openedition.org/coulisses/5098

DOI : 10.4000/coulisses.5098

ISSN : 2546-9460

\section{Éditeur}

Presses universitaires de Franche-Comté

\section{Édition imprimée}

Date de publication : 1 janvier 1997

Pagination : 48

ISSN : 1150-594X

\section{Référence électronique}

Sandrine Mondy, «Un accueil quasi religieux », Coulisses [En ligne], 15 | Hiver 1997, mis en ligne le 26 avril 2019, consulté le 31 octobre 2019. URL : http://journals.openedition.org/coulisses/5098 ; DOI 10.4000/coulisses.5098

Ce document a été généré automatiquement le 31 octobre 2019

Coulisses 


\section{Un accueil quasi religieux}

\section{Sandrine Mondy}

1 Sur la forme générale de la mise en scène, il me semble que ce choix de décor, épuré, valorise le texte, les échanges entre les personnages. Je pense notamment à la scène entre Violaine et Jacques, où cette dernière lui avoue qu'elle a la lèpre. Dans cette scène, l'absence d'« accessoires ", avec comme unique mise en valeur la position des personnages côte à côte, permet d'accentuer la force du dialogue. Et parallèlement, lorsque certains objets sont présents, ils attirent notre regard de spectateur, renforcent leur symbolisme (la table autour de laquelle se retrouvent les membres de la famille, ou le cierge allumé, fort de connotations religieuses). De même, la scène de la fête paysanne était, je pense, parfaitement vivante parce que les éléments présents en étaient caractéristiques (joie rendue par les lumières, la musique...). Le jeu des acteurs était, lui aussi, percutant. Le personnage de Mara surtout, qui, à travers la raideur et la vitesse des mouvements, les contorsions du corps et la dureté du visage, faisait parfaitement ressentir l'obstination, la cruauté et la douleur du personnage. J'ai été étonnée à la fin de la représentation de ne plus reconnaître la comédienne, comme si l'envoûtement de Mara la noire avait pris fin. Moment magique... Le seul détail qui m'a un peu surprise, était l'intervention de la religieuse au caractère un peu... farceur et joyeux, fort éloigné de la gravité (au sens positif!) du reste de la pièce. Mais j'ai réellement passé une excellente soirée, et je vous remercie beaucoup pour cette belle prestation. Et d'ailleurs, le silence « quasi-religieux » qui régnait dans la salle, est une preuve de la réussite de cette représentation, où, à aucun moment, les acteurs ne se sont essoufflés et à aucun moment le public ne s'est ennuyé ! 


\section{AUTEURS}

\section{SANDRINE MONDY}

Elève de terminale littéraire, Lycée L. Lapicque, Epinal 